\title{
Heritage schools: a lens through which we may better understand citizenship and citizenship education
}

Beatrice Szczepek Reed, Fatma Said, and Ian Davies

Address for correspondence

Professor Ian Davies

Department of Education

University of York

Heslington

York

YO10 5DD

Tel: 01904323452

Email: ian.davies@york.ac.uk

\section{$\underline{\text { Abstract }}$}

Heritage schools are part time community-based educational institutions offering language and cultural education. We suggest that the UK government is keen to promote diverse, enterprising, community-based educational action and, simultaneously, keen to promote a particular values-based national identity. In general terms we would expect Heritage schools to be supported for their contribution to communities and as an example of enterprise, but they are instead viewed by the government with suspicion. Following introductory comments, the bulk of the article is given over to an identification of and discussion about 7 tensions in debates about Heritage schools that illuminate thinking and practice about aspects of citizenship and citizenship education. 


\section{Heritage schools: a lens through which we may better understand citizenship and citizenship education}

In a political climate infused by security concerns, vigorous efforts are being made to influence communities. A plethora of initiatives relating to these concerns, including the identification and promotion of Fundamental British Values (FBV), link directly with educational policy and practice and have particular resonance in Heritage (or, supplementary) schools. In this article we explore debates about Heritage schools, arguing that by doing so we can illuminate the nature of aspects of citizenship and citizenship education. We suggest that this illumination allows us to enhance the possibility of positive and consensual educational policy and practice in relation to citizenship issues, generally, and also in relation to specific initiatives about citizenship and character.

In this article we define our key terms, describe relevant contextual matters and discuss 7 key issues that illuminate citizenship and citizenship education. We discuss relevant overarching elements of government education policy; the definition of Heritage schools; their relationship with equality; their meaning in relation to diversity; their contribution to achievement generally; the ways in which they relate to language education; and the possible interactions with policy and practice of citizenship and character education.

\section{Developing our argument about Heritage schools}

This article is not a literature review. Indeed, given the pros and cons associated with systematic reviews of literature (e.g., see MacLure 2005) we did not wish to do that sort of work. However, we have developed our argument about citizenship and citizenship education on the basis of some reading as well as our own academic and professional experience. We used a variety of search strategies to help develop our thinking. Firstly, we used key terms (Heritage schools; British values; character; teachers' perceptions/beliefs; language; ethnicity; diversity) in simple google searches giving 118 rather disparately focused results. Secondly, attempting to refine matters, we achieved 307 results from a search of ERIC using the key words 'supplementary schools UK' with 69 results when the search was restricted to publication since 2011 
(and 250 results when UK was removed). Thirdly, abstracts were reviewed for 20 pages of Google scholar leading to the downloading of 29 articles. Fourthly, this material was supplemented by drawing from other sources. In particular we made use of a recently completed project 'creating citizenship communities' (Davies et al 2014) which included a literature review of 154 studies principally published since roughly the end of the 1990s (to include the publication of the Crick Report, QCA 1998) to 2011, for students aged 11-18 in England (but not excluding reflection on other contexts) with key word searching ('community cohesion', 'citizenship', 'citizenship education' and 'youth community engagement') of several databases (British Education Index (BEI), Education Resources Information Center (ERIC); PsycINFO; Social Policy and Practice; CERUKplus). Finally, there has also been use of material that has been identified through less formal and explicitly declared means.

Recommendations from colleagues, following up items in articles that were identified through formal searches and so on were, as always, useful.

\section{$\underline{\text { Tensions and key questions about Heritage schools }}$}

We are suggesting that Heritage schools provide a lens through which we can think about citizenship and citizenship education. Citizenship is a formal legal and political status, a sense of belonging and identity and also a set of practices (from the passive or at times negatively framed acts of not breaking laws to the more engaged and adversarial aspects of associational life). In this section of the article we draw attention to seven issues about Heritage schools that help reveal the nature of citizenship and citizenship education. We suggest that identifying those issues and seeking to achieve greater clarity about them will help in the development of a professional citizenship dialogue that is likely to enhance the potential for positive community relations generally within the UK and to improve education, specifically within the educational jurisdiction of England.

Issue 1: Overarching considerations of education and policy making in a democracy: promoting freedom and securing control

There is confusion and uncertainty about fundamental matters associated with government educational policy and this impacts on the ways in which Heritage 
schools are characterized and perceived. Debates about these matters illuminate the nature of citizenship. The current (2016) UK government has always signalled its intention in schools in England to ensure that teachers and schools have greater autonomy. We suggest that in terms of a general approach to policy making, structural reform of schools and regarding particular issues there are tensions between the government's desire to promote freedom and, on the other hand, to secure control. In order to achieve the government's goal of freedom in education only certain ideas, structures and perspectives on issues are to be allowed.

The tension in government policy that relates to Heritage schools may be seen across all areas of policy making. The government has promoted FBV. Those values are characterized as follows:

democracy; the rule of law; individual liberty and mutual respect; tolerance of those with different faiths and beliefs (UK Government 2011; Department for Education 2014)

It is unlikely that these values would be opposed by most reasonable people when cast broadly. But the government's statement hides several significant matters. It is not clear why these values are necessarily or exclusively British, or whether they are intended as a goal for - or, an indication of existing practices among - people who live in Britain. It is not clear whether 'democracy' is seen as a value, a process or a system of government. What has been included as FBV is as subject to discussion as what has been excluded (so, for example, there is a clear emphasis on the rule of law as opposed to the right and duty to challenge injustice). The particular way in which FBV connects with education policy and practice is important. The Department for Education has issued considerable guidance about FBV. This is unsurprising as the drive for freedom has always been intended by members of the current government. In 2009 Michael Gove (who would become secretary of state for education in 2010) signalled that action would be taken to deal with a situation in which "teachers have been deprived of professional freedom” http://news.bbc.co.uk/nol/shared/bsp/hi/pdfs/07_10_09govespeech.pdf 
However, this overarching desire to promote freedom is occurring at the same time as a preference for that freedom to be directed towards particular ends. In the same speech as Gove declared his intention to reverse measures which have led to teachers losing freedom he declared that particular approaches would not be tolerated:

We will tackle head on the defeatism, the political correctness and the entrenched culture of dumbing down that is at the heart of our educational establishment.... Out of touch bureaucrats have imposed faddy ideologies on our schools which ignore the evidence of what really works in education.

http://news.bbc.co.uk/nol/shared/bsp/hi/pdfs/07_10_09govespeech.pdf

This general approach to increasing freedom and autonomy, together with tensions regarding control, is also seen in structural school reforms. The rise of Academy Schools (i.e., state funded schools which are free from local authority control) and Free Schools (which have greater freedoms than Academies) seem also to suggest that freedom and autonomy are to be achieved only in specific ways. All maintained schools in England were until very recently required to become Academies (about which there has been strong opposition, e.g., Helm and Adams, 2016, and some softening of the government's approach).

When specific issues are examined a similar approach may be seen to this discussion about freedom and control. The so-called 'Trojan Horse affair' in Birmingham provides an illustration of an issue in which there is a clash between the government's preference for freedom and the perceived need to control in order to achieve that freedom. Some schools in Birmingham with Muslim staff and students were stopped by the government from acting in particular ways due to concerns that diversity was not being respected (Arthur 2015). As perhaps part of that concern for schools to act autonomously but only in relation to actions within officially set parameters, government support is generally not forthcoming for Heritage schools. Once this basic tension between freedom and control and between generic and specific forms of autonomy in relation to fundamental values is considered it should become easier to discuss the educational experience offered by Heritage schools and thereby easier to discuss the nature of citizenship that is being promoted. 
Issue 2: What is a 'Heritage school'?

Broadly, it is possible to indicate the nature of the schools about which we are most concerned:

Supplementary schools provide part-time educational opportunities for children and young people, primarily from Black and minority ethnic communities. They generally offer mother-tongue language classes, faith and cultural studies, activities such as sport, music, dance and drama, and support with National Curriculum subjects. They are established and managed by community members, often on a voluntary basis, and operate from community centres, youth clubs, religious institutions and mainstream schools. Whilst many supplementary schools are small local groups run by parents, others are part of larger organisations that provide a range of services. There are an estimated 3,000-5,000 such schools in England (PHF 2015)

However, as may be seen from the phrasing used in the above quotation and in the context of fiercely contested debates about security and forms of education that are most appropriate to safety and national unity, the very title of 'Heritage schools' is controversial. It is by showing the very wide range of meanings associated with Heritage schools that we are able to identify the nature of how they relate to society. Citizenship issues are obviously relevant when we are considering ways in which communities interact with government. In order to identify the nature of that interaction we need to know how to define or characterize these schools.

There is a sense in which the establishment of these schools suggests that the heritage of those who have (relatively) recently arrived in the UK may be seen less positively than others' backgrounds. If all cultures were regarded equally positively and catered for it might seem unnecessary to establish schools with the purpose of exploring heritage culture. This imbalance between cultures and differences over the value of these schools may suggest that the schools are not necessary or that they would be 
developed only in relation to a deficit model (applied to either the mainstream or as a way of rectifying problems faced within a particular community) (Walters 2011).

Perhaps however, the nature of Heritage (or supplementary) schools are even more fundamental. The boundaries of what might count as 'Heritage' are very fluid. If a parent for example were to offer support for their child by taking them to an out of school club is that relevant to Heritage? If additional tutoring was offered (in almost any subject) would that possibly be seen as necessary for particular Heritage groups? This issue may be raised as Heritage schools are not all the same (Hall et al 2002) refer to 4 types of school that focus on different objectives: mother tongue; religious; culture and history; supplementary mainstream. Maylor et al (2010) provide a fairly similar outline:

The first category of schools is those designed to support children in mainstream educational subjects, where the provision is intended to raise the level of success in educational attainment.... The second category is made up of schools which aim to maintain the cultural and/or language traditions of a particular community.... The final category of schools is those which are organised to promote educational and other values that are distinctly counter to the values found in mainstream education.

Maylor et al suggest it may be possible to relate some of these different types of school to particular groups. Attempts to raise achievement in mainstream schools may, for example, be perceived to be particularly pertinent to Afro-Caribbean students; an emphasis on cultural and language traditions may apply for example to students of Asian heritage in Leicester; and opposition to mainstream educational thinking may be found among those groups that prefer home schooling. But, of course, these are generalizations which may be completely inappropriate to specific circumstances and they are not the only purposes and groups that could be mentioned. Perhaps much additional schooling paid for by parents or others could be seen as relating to this field. Bregvadze (2012, p.80) for example refers to:

fee based supplementary instruction to children in academic subjects that they study in the mainstream education system. 
As well as the very significant differences between the focus of these schools there are differences in practical arrangements. Some have attempted overarching descriptions although the extent of difference is very significant. Hall et al suggest that these schools are voluntary; poorly funded; occupy poor accommodation; are staffed by untrained teachers; and enjoy high levels of parental and community support. Students are taught in mixed groups by ability, age and at times (but not always) separately by gender. The ethos of the schools is often characterized by discipline and formality with the curriculum designed to promote pride in one's home culture and community language(s). But these things are by no means common. Generally, the schools promote group solidarity with community interest being seen as important as individual interests and with a keen interest in the nature and amount of progress being achieved by their students when they are in 'mainstream' schools. The above suggests that tensions about Heritage schools are likely to arise in light of their very varied nature. The plasticity of Heritage schools reveals issues about the nature of the relationships between those who set educational policy and the citizens who are affected by it and those who seek to establish particular approaches in relation to it. In order to achieve a common citizenship is it necessary to establish a common school?

Issue 3: What is the relationship between equality and Heritage schools?

There are some who seem to suggest that certain sorts of Heritage schools may not be congruent with a positive commitment to equality. If that is the case then there are likely to be tensions about Heritage schools and there will be obvious ramifications for an overarching sense of citizenship. Ventura and Gomes (2013) suggest in a context where there is a rising middle class, entrepreneurs who want to make money, and where there is competition for high stakes outcomes "supplementary education is a result of quality deficiencies and inequity” (p.129). Thus, there is the possibility that growth in the number of Heritage schools may contribute to an increase in inequality. This point is connected strongly to debates about the ways in which individuals and groups are empowered relative to the state. Zhang (2014) suggests that the growth of what might be termed enterprise in education leads only to corruption. Essentially the argument is that teachers encourage families to pay extra for what should already 
have been provided and that the take up of such offers (which may or may not be beneficial) varies across urban and rural as well as other divides thus heightening negative social conditions.

However, it is important to make a distinction between what might be deemed to be the outcomes of the flexibility indicated by the existence of Heritage schools and the various motivations for the establishment, and use of, such schools. Civitas, for example, reviving arguments about the alleged inequity that was achieved through state intervention in the history of education, suggest that supplementary schools may be seen positively (Seddon, Cowen and Tree 2006). Their view is that the right for parents to set up their own schools is an expression of a healthy civil society. For very different reasons (and in the absence of any stated commitment to economic reward) there is also support for Heritage schools from those who point positively to Black Sunday schools and socialist Sunday schools (e.g., Gerrard 2011; Mirza and Reay 2000). The desire on the part of the current Conservative government in the UK to have schools that are 'fully integrated with the local community, responsive to local parents and, crucially, connected with, learning from and supporting other schools', rather than their behaving 'as islands, making their own way' (Morgan 2015) does not (unlike previous governmental positions, see DfES 2003) actually suggest official support for supplementary schools. The liberalism offered by the current government may be more closely aligned with the perspectives offered, for example, by Seddon et al than Gerrard. But it would be unreasonable to establish narrow boundaries around the characterization of certain actions. The development of Heritage schools may be congruent with the drive from many to encourage parents to become engaged (e.g. Bastiani 2000, Chowdry et al 2009, Strand 2007). In relation to specific groups that are not always involved in schools there is at times seen to be particular benefits that may be achieved through the heritage movement. For example,

Chinese language schools foster a sense of civic duty in immigrants, who are often criticized for their lack of civic participation (Zhou and Li 2003, p.69)

In part the difficulties about making sense of these distinctions and overlaps may relate to 3 complex debates about equality and education. 
Firstly, Heritage schools may be more or less loosely connected to the state. Karsten (2006) suggests that states may be intrusive, emphasise self-provision or be facilitative in the achievement of education. And these different approaches may be seen to work more or less effectively. These different perspectives lead to different actions. In England, Karsten suggests, no state money would be given directly to independent schools; in some countries private schools may receive government grants (France, Italy, Portugal); and in some locations there are grant aided private schools (Ireland, Germany, Belgium, Denmark, Sweden, Luxembourg). These practical matters can also be recognized through the particular ways in which initiatives are managed and whether or not intended outcomes are achieved. In the US, for example, the attempt to provide, through supplementary education services (SES), support for those in greatest need is largely regarded as having failed. Mesecar (2015) suggests that "the federal government created and defined the operation of the SES market but was not a direct consumer of its services [and the initiative] was ultimately compromised by unrealistic aspirations and unclear mandates” (p.4).

Secondly, beyond practical issues of what occurs there are ideological preferences that are relevant to Heritage schools and issues of equality. In essence the existence of Heritage schools suggests that preferences are being expressed for particular forms of liberalism. In some forms of liberalism there will be allowances made for flexibility within a common approach but in others there may be decisions made about the right of groups to establish what they wish, even if that is in opposition to the values of the state. We will return to this point below in discussing reactions to perceived radicalization but will state briefly here that where official preferences exist for commonality we may perceive less commitment to multiculturalism and more attention directed towards civic integration.

Thirdly, and most fundamentally (beyond practical matters and distinctions about types of liberalism) there are very different perspectives on the nature of the private and public divide. While some commentators have suggested that the direction of travel in many countries is simply towards a neo-liberal approach others have argued for a more nuanced and complex perception about the characterization of what is private and what is public: 
Despite the seemly monolithic momentum towards privatisation with its powerful discourses on a global scale, the private education sector is vastly heterogeneous (Day Ashley 2013, p.210; also see Boyask 2013).

Power and Taylor (2013) by reference to "home schooling, religious supplementary schools and maintained faith schools” suggest that a struggle for recognition is ongoing (p.468). They justify this position by arguing:

it cannot be implied that there is a linear and one-directional relationship between the rise of the private sphere and greater social injustice, primarily because what constitutes the 'private' is perhaps more fluid than is often assumed. Relatedly, the second main conclusion is that it must be recognised that social justice is multidimensional, and that the positive influence of the public or private sphere in one dimension may have negative consequences in another dimension. ......A broader sense of the public sphere would recognise not one public but many. It would not be a public sphere that was commensurate with the state, but one which would hold the state to account (Power and Taylor 2013, p.476)

It is not possible to provide a simple summary of all the many issues relevant to the above but Maussen and Bader (2015) refer to 4 transformations that may be relevant: secularisation; the personalisation of politics; relations between state and society involving "welfare state recalibration" (p.5); and the impact of "supranational human rights regimes” (p.6). These authors usefully suggest that there are tensions that exist within and between supplementary schools. Those tensions are:

1. The right to freedom of education interpreted as parental choice can conflict with the (proto-) freedoms of pupils, increasingly gaining in 'autonomy'.

2. Organisational, educational, and pedagogical freedoms of religious schools may conflict with principles and rights of non-discrimination.

3. Associational freedoms of religious schools to select students can be in tension with rights of equal educational opportunities for all. 
4. Educational/pedagogical freedoms of religious schools may conflict with demanding requirements of teaching and learning democratic citizenship and democratic virtues.

5. Far-going decentralisation or autonomy of schools and teachers (in general, for religious schools in particular) combined with the monitoring and guaranteeing of educational performance, is a challenge for educational systems in general (p.10)

In light of the above we wish to suggest that the meaning of equality is of immediate relevance to our developing understanding of Heritage schools. Simple insistence that Heritage schools do (or, do not) promote equality are unlikely to be meaningful. The complexities associated with Heritage schools and equalities mean that it is highly likely that there will be tensions in discussions about those schools. These debates suggest that Heritage schools are a lens through which citizenship issues are revealed. We also suggest that many of the debates about equality are very closely connected to discussion about diversity and we turn to that area now.

\section{Issue 4: Diversity and Heritage schools}

The nature of citizenship is revealed by considerations about diversity. Heritage schools provide a platform on which we can identify and explore diversity. All societies are - and have always been - diverse but in part due to the greater regulation of movements across countries and the economic and other imperatives and effects of contemporary globalization there may seem a greater obviousness to the existence of diversity. In particular locations there may be higher levels of migration which makes the existence of diversity easier to identify. For example,

Projections show that there is likely to have been an average increase of 10 per cent in the number of foreign-born residents across all English regions since the 2011 census (Ramalingam and Griffith 2015, p. 5).

Social diversity links directly to the development of Heritage schools: 
There are two key reasons for the existence of supplementary schools in the UK. Firstly, supplementary schools were set up by minority ethnic community members in order to maintain the language and customs of their country of origin, and a desire to preserve their cultural/ethnic identities and/or faith/traditions (Maylor 2010, p.29).

In part that recognition of specific need is aligned with perceptions by some of the appropriateness of allocating public resources to Heritage schools and this, of course, links with many of the points made above about equality. Some suggest a difficult relationship between cohesion and diversity (e.g., Letki 2008). Ahmed (2012) has suggested that only an unhelpfully limited form of diversity is currently accepted:

The difficulty for liberals is that individual autonomy rests on truths they consider to be 'self-evident' and universal. Whilst liberalism argues that reason must challenge dogma, many non-western peoples challenge nonnegotiable liberal truths as dogmatic and oppressive (p.728).

In part concerns over diversity may be fuelled by the media. The Sunday Telegraph on October 25, 2009 alleged that 'Islamists who want to destroy the British State get $£ 113,000$ in funding’. Concern may also be a reaction to the statements of politicians. David Cameron (Vaughan 2015) has said:

Let me be clear: there is nothing wrong with children learning about their faith, whether it's at madrassas, Sunday schools or Jewish yeshivas. But in some madrassas, we've got children being taught that they shouldn't mix with people of other religions; being beaten; swallowing conspiracy theories about Jewish people. These children should be having their minds opened, their horizons broadened, not having their heads filled with poison and their hearts filled with hate.

In this context of fears about diversity a new school inspection regime has been developed to apply to religious institutions offering eight or more hours of study a week to children in England. Additionally, there have been significant changes to government policy some of which applies directly to education. The Prevent Strategy 
(2011) is to be interpreted alongside the School Inspection Handbook (Ofsted January 2015), the duty to promote fundamental British values as part of (Spiritual Moral Social and Cultural) SMSC in schools (November 2014) and the recently published Departmental advice for schools and childcare providers about radicalisation.

These concerns about integration are closely associated with heritage schools. Malouf et al (2006) has suggested that one of the motivations for such schools is an attempt to serve the needs of young people.

Loss of heritage culture may precipitate a variety of relational and psychological stresses in Vietnamese-American youth, leaving them bereft of a strong sense of cultural identity. As they assimilate into US youth subcultures, academic performance of Vietnamese students tends to decline (Zhou \& Bankston, 2000), and some resort to negative behaviour at school or even turn to delinquent or gang-related activity in the quest for a new identity (Long, 1996; Zhou, 1996). Lack of proficiency in the heritage language also contributes to intergenerational conflict as children become frustrated when they are unable to communicate effectively with their relatives or with peers in the old country. As family relationships weaken, parental authority correspondingly weakens, the older generation is hampered in its efforts to transmit ethnic values, and family unity often diminishes (Hinton, 1999; Wong-Fillmore, 1991) (p.256).

If one were to assume that Heritage schools are providing much needed education a positive relationship with government would be expected. Indeed it might be felt that the general direction of government policy in its commitment to autonomy which can be seen in Cameron's emphasis on the 'big society' would be congruent with heritage schools. In that 'big society':

..... people, in their everyday lives, in their homes, in their neighbourhoods, in their workplace, don't always turn to officials, local authorities or central government for answers to the problems they face, but instead feel both free and powerful enough to help themselves and their own communities. (Cameron 2010) 
However, it seems that the UK government sees supplementary schools as part of the way in which division is created in society. The Prevent Strategy is critical of the previous Labour governments' efforts to promote integration. The RSA in a recent study (Nwulu 2015) noted that many Heritage schools were disappointed by the lack of positive government interest and engagement which may lead to isolation:

Supplementary schools often have unproductive, fragile partnerships with mainstream schools (p.37).

These tensions about the place of Heritage schools in a diverse society may be connected to 2 key debates. Firstly, and very generally, there are issues about what is the best way to think about and achieve an integrated and diverse society where both inclusion and difference are allowed. Malouf et al point to 3 general approaches: either assimilation of the 'guest' to 'host' culture; or, a position in which integration and separation are seen on a spectrum with agreement to be established about an optimum point on that spectrum; or, a recognition that identity is situational and as such there will be different expressions of commonality or difference dependent on circumstances. These perspectives are often not stated explicitly and as such disagreements about diversity may be hard to resolve. The second debate in which difficulties about the place of Heritage schools in a diverse society may be seen is rather more precisely framed. Essentially, there are questions around what is taught and how (and what sort of impact is intended and achieved). Debates about diversity cannot be conducted on the basis of assumptions of uniformity. Different faith groups will want different things (e.g. Fincham and Lydon 2014). Governments who may introduce so-called progressive measures such as Liberal Education in Hong Kong (Chan and Bray 2014) may be opposed by parents who want traditional didactic teaching. And the teaching of Religious Education (RE) is complex. Moulin (2015) writes of RE losing its essence post 9/11 becoming something to strengthen civic tolerance rather than pursue 'truth'. Conroy et al (2014) feel that RE has been asked to do too much. And Orchard (2015) suggests that 
Causal links between RE as a curriculum subject and a distinctive transformative effect on the attitudes and social behaviour of children and young people have not been proven reasonably beyond doubt (p.51)

What seems clear from the above is that Heritage schools are positioned centrally in extremely tense debates. It is unlikely that these schools will be easily accepted by all but they do provide a lens through which citizenship is revealed.

Issue 5: What contributions are made by Heritage schools to achievement?

The debates referred to above about equality and diversity may have particular meaning in relation to specific educational outcomes. While there are legitimate debates about the purpose of Heritage schools there is also a need to ask, perhaps at times rather narrowly and in the context of pressures to achieve academic and other goals across the education sector, whether they make a positive contribution. The nature of citizenship is revealed in part in relation to functionality (can citizens operate within society) and excellence (are we providing the best for citizens). As such we can explore issues of citizenship by considering whether the schools that are established in a society are 'good' schools. There are some extremely thorough reviews of the work of Heritage schools (e.g. Evans 2008; Jones 2015; Maylor et al 2010) but perhaps unsurprisingly given their variation there is little consensus about their outcomes.

Ramalingam and Griffith (2015, p.9) suggest that heritage schools provide:

1. Extended learning and enrichment

2. Rich and personalised learning

3. Confidence and cultural competence

4. Mother-tongue proficiency and bilingualism

5. Role models

6. Parental involvement

7. Community mediation and social integration 
Fairburn-Dunlop (2014) found that "students stated quite emphatically that the knowledge, skills and confidence they gained in Poly [a heritage school] were what supported them to connect to culture, to other communities and to education” (p.884) and that "Poly had been an important avenue to their further social, cultural and educational participation” (p.890). Chine and Tucker (2005) argued on the basis of their study that:

There is a strong relationship between the participants' sense of ethnic identity, attitudes toward the JHL [heritage] school and self-assessed proficiency in Japanese (p.27).

Evans and Gillan-Thomas (2015) suggest that heritage schools promote confidence and well-being. Tereschchenko and Grau Cárdenas (2013) provide a list of potential benefits. Strand (2007) suggests that students enjoy going to supplementary schools.

On the other hand, there are some authors who express reservations about the contributions that supplementary schools make to students' achievements and attainments. Rose (2013) suggests that:

When shadow education becomes widespread, teachers may feel that their students have a safety net outside the school and therefore that the teachers do not need to work as diligently as they might when shadow education is not common (p.365).

and Chan and Bray (2014) argue that:

students may reduce their respect for and reliance on their teachers and school curriculum, and instead place more emphasis on the shadow sector (p.365).

Many of the accounts about achievement seem assertive and judgmental with evidence not used or it seeming to be rather inconclusive or inconsistent. This may be because there are such different experiences available. The varied purposes of schools referred to earlier may be important. Rose (2013) and Chan and Bray (2014) were 
exploring schools that were deliberately supplementary to the mainstream rather than those that aimed at providing something culturally and linguistically distinct. But even when the latter perspective is adopted the evidence is patchy. Tereshchenko \& Archer (2015), for example, argue that students found Bulgarian school hard and boring and so they liked mainstream schools more; but Albanian schools were seen as being more friendly leading to or being a demonstration of a stronger Albanian identity and revealing a situation in which students were not always positive about the UK. What is the contribution made by Heritage schools to achievement? As we do not know there are likely to be tensions in the debates about these schools. If we want to know more about citizenship we need to know more about achievement. Again, Heritage schools provide the lens through which we can explore citizenship.

\section{Issue 6: How do Heritage schools relate to language education?}

The role of language is vital for any consideration of the nature and purpose of Heritage schools and the contributions that they might make to identity and community and so to citizenship. Superficially, it might be imagined that they contribute to language development but there are many debates about this matter.

For some, language is closely related to rights. Starkey (2002) refers to the purpose of the International Covenant on Civil and Political Rights (1966) as well as Article 14 of the European Convention on Human Rights (1950) as protecting individuals against discrimination in their entitlement to rights and which specifically mention language in this respect. He quotes from Article 27 of the International Covenant which refers to linguistic minorities within states:

Persons belonging to such minorities shall not be denied the right, in community with the other members of their group, to enjoy their own culture, to profess and practise their own religion, or to use their own language.

When language rights have been abrogated it is clear that an injustice has been done. However, Schiffman provides a fascinating study of language rights in revolutionary France, Stalinist Russia and $20^{\text {th }}$ and $21^{\text {st }}$ century America. He shows that the 
determination to use one language and discount others can be motivated by the desire for justice. He quotes Barrère who on $27^{\text {th }}$ of January 1794 addressed the Convention:

The language of a people ought to be one and the same for all. Our enemies had made the French language into the language of the courts; they vilified it. It's up to us to make out of it the language of the people, and to honor it. Federalism and superstition speak Breton; emigration and hate for the Republic speak German; counterrevolution speaks Italian, and fanaticism speaks Basque. Let us smash these instruments of damage and error.

In the US foreign language learning was banned in certain states during the period 1917-23 and subsequent official restriction was not necessary for the continuation of that prohibition.

But not all those who are interested in language development would accept this political perspective. There is a lack of consensus about the relationship between language and identity. Malouf (2006) on the basis of research with VietnameseAmericans an emphasising the importance of age at arrival in a country and family milieu concluded:

Results of this study at least offer the possibility that an integrative cultural identity, with its appreciation for values of both cultures and dual sense of belonging, is a feasible outcome of acculturation, even when additive bilingualism is not present (p.268).

In other words language may not be as important for identity as people sometimes assume. But much of the literature seems to assume a connection. Francis, Archer and Mau (2009) suggest that language is vital for identity and may be seen as capital in that it allows one to do things, and assists in the replication of culture. This connection between language and identity is fundamentally important to any consideration of the role of Heritage schools. He (2004) explains: 
Fishman (1989) suggested heritage language schools are guided by the following assumptions: (1) that there is a consequential link between language and ethnicity, (2) that there is a possibility, feasibility and necessity of biculturalism and bilingualism, and (3) that the promotion of bilingualism and biculturalism occurs through planning and organisation (p.256).

Given the above, arguments are then made by those in favour of connecting language acquisition and identity for particular sorts of action to be undertaken. He (2004) refers to the skills needed for bicultural competence:

(1) knowledge of cultural beliefs and values, (2) positive attitude toward both groups, (3) bicultural efficacy, (4) communication competency, (5) role repertoire and (6) groundedness (p.257).

And He (2004) completes the circular relationship between language and culture by asserting:

As Norton (1997) observed, language, speakers and relationships are inseparable. Ethnic identity is understood to refer not only to nominal selfidentification as a member of an ethnic group, but also to belongingness (how much the individual feels a part of the group), centrality (how important the group is for personal identity), evaluation (positive or negative feelings about the group) and tradition (how much one practises ethnic behaviours and values) (Ward, 2001)” (p.259).

In light of the perceived link between language and identity it is then perhaps a small step for some to assert the various connections that may be made between language teaching and social and political matters. Hosack (no date) argues:

Foreign language teachers can promote global citizenship by adopting content that addresses citizenship themes; by focusing on cross-cultural comparisons in order to develop students' intercultural competence; and 
by training students in communication skills that are essential for democratic dialogue.

The above seems to suggest that the role of Heritage schools which emphasise the significance of language teaching may be relevant to considerations of social and political matters. However, such contexts are controversial even among those who embrace political perspectives and many who research and teach language focus on very different matters. Language for some is a personal, cultural and academic matter; and entanglement in political debates is seen by them as controversial. Chine and Tucker (2005), for example, explain without any reference to political issues:

The term 'heritage language' denotes a language other than English that is associated with an individual's ethnic or cultural background and a 'heritage speaker' is someone who speaks or understands a language (other than English) that was spoken at home (p.27).

What is clear is that Heritage schools that focus on language provide a lens through which we can reflect on citizenship.

Issue 7: What are the interactions between Heritage schools and citizenship and character?

Heritage schools are interested in the development of citizens of good character. Berkowitz (2012) has suggested that character education is "the deliberate development, in schools, of youth’s tendency and capacity for responsible, pro-social, and respectful democratic citizenship in our society” (p.1). The UK government (Department for Education 2015) has recently promoted character education suggesting that it entails:

perseverance, resilience and grit, confidence and optimism, motivation, drive and ambition, neighbourliness and community spirit, tolerance and respect, honesty, integrity and dignity, conscientiousness, curiosity and focus. 
The link between language (a central purpose of many Heritage schools), citizenship and character is seen by some as being strong. The works of Starkey (2002), Byram (2008), Blackledge and Creese (2013), Creese (2009), Shapiro (1981) and others (e.g. Hosack, no date) are directly relevant to citizenship. Very well-known instances of political education (e.g. Freire 1972) are essentially concerned with the power of the word and of recognising the illogicality of imagining a neutral education (it is, according to Freire, for domestication or liberation). Many of the points referred to above have already made the connection between language, culture, citizenship, character and, by extension, Heritage schools.

The context that informs the development of citizenship and character education includes significant controversies and tragedies. Arising from allegations of attempted political indoctrination by teachers, legislation was introduced into the 1986 Education Act (number 2) to govern treatment of partisan issues and has been incorporated into subsequent legislation. There is a legal duty on schools and teachers to ensure that partisanship does not occur and that when political material is discussed there is a "balanced presentation of opposing views".

This history of education for citizenship does not need to be rehearsed again here. But we wish to draw attention to certain issues that demonstrate the connection between citizenship education and matters relevant to Heritage schools. The nation state is often deemed to be the most obvious starting point for understanding the nature of a citizen. Crick (following Arendt) asserted that "a citizen is by definition a citizen among citizens of a country among countries” (2001, p.138). The connection then between citizenship and fundamental British values is strong. The basis for the development of citizenship education was 'new' Labour's commitment to communitarianism. The power of local communities is obviously significant for heritage schools. The nature of citizenship education changed especially in relation to issues about diversity. Following the murders of British citizens in London in 2005 the Ajegbo (2007) report recommended altering citizenship education to include ‘identity and diversity'.

Since the election of a Conservative-led government in 2010 there have been significant developments. The emphasis on requiring schools to promote national 
identity and patriotism was strengthened. Michael Gove the secretary of state for education from 2010 claimed that schools were depriving children of "one of the most inspiring stories I know - the history of our United Kingdom”. The 2011 riots in English cities were also influential in the development of a particular approach to the teaching of social and political issues. David Cameron suggested that there was a need to mend the "broken society" in which there were:

children without fathers; schools without discipline; reward without effort; crime without punishment; rights without responsibilities; communities without control

Citizenship education (perhaps because of legislative complexities introduced in the late 1980s when the National Curriculum was first established which were designed to prevent future governments tinkering) remained in schools. But although inspection and research evidence indicating its value has been very strong, (e.g., Ofsted 2013; Whiteley 2012; Keating, et al, 2010) the changes made in 2014 to citizenship education were dramatic. Instead of highlighting key concepts (democracy and justice; rights and responsibilities; identity and diversity), key processes (critical thinking; advocacy and representation; informed and responsible participation) through the analysis of relevant content, the revised National Curriculum emphasizes civic knowledge of UK governance and the justice system, commitment to volunteering and thinking critically so students can manage their money on a day to day basis. Autonomy may be allowed but it is for a narrowly defined purpose.

Similarly there are longstanding debates about the nature and value of character education (e.g. Arthur 2003; Davies, Gorard and McGuinn 2005). The most prominent UK centre is based at the University of Birmingham (http://www.jubileecentre.ac.uk/). Currently it has cross party support from Secretary of State for Education, Nicky Morgan and Tristram Hunt (former opposition spokesperson on education). There are criticisms. Kristjansson (2013) has defended it by attempting to rebut criticisms that it is "unclear, redundant, old-fashioned, religious, paternalistic, anti-democratic, conservative, individualistic, relative and situation dependent”, whilst accepting that there are also "better founded problems". 
Winton (2007) for example, sees it as assimilationist and Hanson, Dietsch, and Zheng (2012) were not able to identify any positive impacts.

Summarising developments in relation to character and citizenship it is possible to suggest that by 2010 citizenship education had become increasingly clearly professionally articulated and implemented in schools. But as the Labour government had endorsed citizenship education, legitimation would be a problem when the government changed. This shift in citizenship education and the greater emphasis on character education has taken place in a context where there is less public money available for a relatively new subject. When allied with the fear of radicalization and the difficulties in the United Kingdom of promoting a straightforwardly nationalistic citizenship an emphasis on character seems more desirable to the current government. There seems to be potentially strong connections between the trends and issues in citizenship and character education and the work of Heritage schools. The connections with the nation state, the extent of criticality, the reliance on collective and/or individual matters are all centrally relevant to debates about Heritage schools.

\section{Conclusion}

High profile national security concerns in the context of perceived Islamic radicalization are occurring at the same time in which education policies encourage autonomy for parents and teachers. There is likely to be uncertainty in such a context about the nature, role and purpose of Heritage schools. This uncertainty connects to issues of overarching government policy, the definition of Heritage schools and their place regarding equality and diversity, the nature of achievement in schools, the role of language education, citizenship and character education. All these matters are connected to overarching and specific characterizations of citizenship and have relevance for the way in which citizenship and character education may develop.

It would be naïve to suggest that these uncertainties may be resolved easily. However, we argue both that by identifying and discussing these matters we enhance our opportunities to have discussions that are more meaningful and, possibly, more positive. The 7 issues that we have identified in this article throw light on the nature of aspects of citizenship and citizenship education. Heritage schools are the lens 
through - or the arena within - the essential struggles over citizenship are taking place. Research work in Heritage schools would help to clarify the nature of these debates still further.

\section{List of References}

Ahmed, F. (2012). Tarbiyah for shakhsiyah (educating for identity): seeking out culturally coherent pedagogy for Muslim children in Britain, Compare, 42:5, 725-749

Ajegbo, K. (2007). Diversity and Citizenship: Curriculum Review. London, DfEs.

Arthur, J. (2003). Education with Character. The moral economy of schooling. London, RoutledgeFalmer.

Arthur, J. (2015). Extremism and Neo-Liberal Education Policy: A Contextual Critique of the Trojan Horse Affair in Birmingham Schools, British Journal of Educational Studies, 63:3, 311-32.

Bastiani J (2000) Supplementary Schooling in the Lambeth Education Action Zone, IPPR. http://www.ippr.org/assets/media/uploadedFiles/research/projects/ Education/Bastiani.doc

Berkowitz, M. (2012). Understanding effective character education. CSEE Connections, December 2011-January 2012, the Center for Spiritual and Ethical Education. http://www.character.org/wp-content/uploads/2011/12/UnderstandingEffective-Character-Education.pdf (accessed 29 January 2016)

Blackledge, A., and Creese, A. (2013) Heteroglossia in English Complementary Schools. Pages 123-142 in Gogolin, J. and J. Duarte (eds.) Linguistic super-diversity in urban areas. Amsterdam, John Benjamins. 
Boyask, R. (2013). Theorising the democratic potential of privatised schools through the case of free school. Critical Perspectives on Communication, Cultural \& Policy Studies, 32,1/2, 11-26.

Bregvadze, T. (2012) Analysing the Shadows: Private Tutoring as a Descriptor of the Education System in Georgia. International Education Studies; 5, 6.

Byram, M.S. (2008). From Foreign Language Education to Education for Intercultural Citizenship. Essays and Reflection. Clevedon: Multilingual Matters.

Cameron, D. (2010). The Big Society. (http://www.number10.gov.uk/news/speechesand-transcripts/2010/07/big-society-speech-53572, accessed 20 October 2015).

Chan, C. \& Bray, M. (2014) Marketized private tutoring as a supplement to regular schooling: Liberal Studies and the shadow sector in Hong Kong secondary education, Journal of Curriculum Studies, 46:3, 361-388.

Chine, K. \& Tucker, I.G.R. (2005) Heritage Language Development: Understanding the Roles of Ethnic Identity and Saturday School Participation. Heritage Language Journal 3:1. http://www.international.ucla.edu/media/files/chinen_and_tucker.pdf

Chowdry H, Crawford, C. and Goodman, A. (2009). Drivers and Barriers to Educational Success: Evidence from the longitudinal study of young people in England, Department for Children, Schools and Families.

http://discovery.ucl.ac.uk/18314/1/18314.pdf

Conroy, J., D. Lundie, R. Davis, V. Baumfield, P. Barnes, T. Gallagher, K. Lowden, N. Bourque, and K. Wenell (2014). Does Religious Education Work? A Multidimensional Investigation. London: Bloomsbury.

Creese, A. (2009). Building on Young People's Linguistic and Cultural Continuity: Complementary Schools in the United Kingdom, Theory Into Practice, 48:4, 267-273

Crick. B. (2000). Essays on Citizenship. London, Continuum. 
Davies, I., Gorard, S., \& McGuinn, N. (2005). Citizenship education and character education: Similarities and contrasts. British Journal of Educational Studies, 53(3), 341-358.

Davies, I., Sundaram, V., Hampden-Thompson, G., Tsouroufli, M., Breslin, T., Thorpe, T., \& Bramley, G. (2014). Creating citizenship communities: education, young people and the role of schools. Palgrave Macmillan.

Day Ashley, L. (2013) The shifting politics of the private in education: debates and developments in researching private school outreach in India, Comparative Education, 49:2, 206-225

Department for Education and Skills (DfES) (2003). Aiming High: Raising the Achievement of Minority Ethnic Pupils. DfES/0183/2003. London DfES.

Department for Education (2014). Promoting fundamental British values as part of SMSC in schools. Departmental advice for maintained schools. London, DFE-006792014.

Department for Education (2015). DfE Character Awards application window now open. https://www.gov.uk/government/news/dfe-character-awards-applicationwindow-now-open (accessed 29 January 2016).

Evans, D. (2008). Evidencing Impact and Quality of Supplementary Education in Barnet: Summary report to The London Borough of Barnet and Barnet Children's Fund, May 2008

Evans, D. and Gillan-Thomas, K. (2015). Supplementary Schools: Descriptive analysis of supplementary school pupils' characteristics and attainment in seven local authorities in England, 2007/08 - 2011/12, Paul Hamlyn Foundation.

http://www.phf.org.uk/wp-content/uploads/2015/05/PHF-supplementary-schoolsanalysis-final-report-alt-image1.pdf 
Fairbairn-Dunlop, P. (2014). The interface of Pacific and other knowledges in a supplementary education site, Compare, 44:6, 874-894

Fincham, D. and Lydon, J. (2014). Towards Academy Conversion: Challenges and Opportunities for Catholic Schools. Journal of Studies in Social Sciences 9, 2, 159195

Francis, B., Archer, L. and Mau, A. (2009). Language as capital, or language as identity? Chinese complementary school pupils' perspectives on the purposes and benefits of complementary schools. British Educational Research Journal, 35, 4, pp. $519-538$

Freire, P. (1972). Pedagogy of the Oppressed. Harmondsworth, Penguin.

Gerrard, J. (2011) Gender, community and education: cultures of resistance in Socialist Sunday Schools and Black Supplementary Schools. Gender and Education, 23:6, 711-727

Hall, K. A., Özerk, K., Zuldiqar, M., and Tan, J. E. C. (2002) 'This is Our School’: provision, purpose and pedagogy of supplementary schooling in Leeds and Oslo. British Educational Research Journal, 28, 3, 399-418.

Hanson, T., Dietsch, B., and Zheng, H. (2012). Lessons in Character Impact Evaluation. (NCEE 2012-4004). Washington, DC: National Center for Education Evaluation and Regional Assistance, Institute of Education Sciences, U.S. Department of Education

He, A.W. (2004). Identity construction in Chinese heritage language classes. Pragmatics 14:2/3.199-216.

Helm, T. and Adams, R. (2016). Tory plan on academies faces cross-party opposition. The Guardian 26 March, http://www.theguardian.com/education/2016/mar/26/academy-schools-plancross-party-opposition-councillors-anger (accessed 3 May 2016). 
Hosack, I. (no date) Literature review for PhD thesis. University of York.

Jones, C. J. (2015). Characteristics of Supplemental Educational Services Providers That Explain Heterogeneity of Effects on Achievement. Educational Policy, 29(6) 903-925.

Karsten, S. (2006). Freedom of Education and Common Civic Values. European Education, 38:2, 23-35

Keating, A., Kerr, D., Benton, T., Mundy, E. and Lopes, J. (2010). Citizenship education in England 2001-2010: young people's practices and prospects for the future: the eighth and final report from the Citizenship Education Longitudinal Study (CELS). London, Department for Education.

Kristjánsson, K. (2013). Ten Myths About Character, Virtue and Virtue Education - Plus Three Well-Founded Misgivings, British Journal of Educational Studies, 61:3, 269-287.

Letki, N. (2008). Does Diversity Erode Social Cohesion? Social Capital and Race in British Neighbourhoods. Political Studies 2008. 56(1): 99-126.

Malouf, V. M., Rubin, D. L. and Miller, A. N. (2006). Cultural Competence and Identity in Cross-cultural Adaptation: The Role of a Vietnamese Heritage Language School. The International Journal of Bilingual Education and Bilingualism 9, 2, 255273.

Maylor U, Glass K, Issa T, Kuyok K, Minty S, Rose A, Ross A, Tanner E, Finch S, Low N, Taylor E, Tipping S and Purdon S (2010) Impact of Supplementary Schools On Pupils’ Attainment: An Investigation Into What Factors Contribute To Educational Improvements, Department for Children, Schools and Families. http://dera.ioe.ac.uk/810/1/DCSF-RR210.pdf 
Maussen, M. \& Bader, V. (2015) Non-governmental religious schools in Europe: institutional opportunities, associational freedoms, and contemporary challenges, Comparative Education, 51:1, 1-21.

Maylor U, Glass K, Issa T, Kuyok K, Minty S, Rose A, Ross A, Tanner E, Finch S, Low N, Taylor E, Tipping S and Purdon S (2010) Impact of Supplementary Schools On Pupils’ Attainment: An Investigation Into What Factors Contribute To Educational Improvements, Department for Children, Schools and Families. http://dera.ioe.ac.uk/810/1/DCSF-RR210.pdf

MacLure, M. (2005)'Clarity bordering on stupidity': where's the quality in systematic review?, Journal of Education Policy, 20:4, 393-416.

Mesecar, D. (2015). The rise and fall of supplemental educational services: Policy implications for government markets. AEI Research. https://www.aei.org/wpcontent/uploads/2015/01/The-Rise-and-Fall-of-Supplemental-EducationalServices.pdf (accessed 29 January 2016).

Mirza, H. S. and Reay, D. (2000). Spaces and Places of Black Educational Desire: rethinking black supplementary schools as a new social movement. Sociology, 34, 3, 521-544.

Morgan N (2015) 'Nicky Morgan speaks about the importance of school governance', speech made to the National Governors’ Association Summer Conference, 27 June 2015, Department for Education. https:/www.gov.uk/government/ speeches/nickymorgan-speaks-about-the-importance-of-school-governance

Moulin, D. (2015). Religious Identity Choices in English Secondary Schools. British Education Research Journal 41 (3), 489-504.

Nwulu, S. (2015). Beyond the school gates. Developing the roles and connections of supplementary schools. London, RSA.

PHF (2015). Supplementary schools case studies. London, PHF 
Ofsted (2013). Citizenship Secured. London, HMSO.

Orchard, J. (2015) Does religious education promote good community relations?, Journal of Beliefs \& Values, 36:1, 40-53

Power, S. \& Taylor, C. (2013) Social justice and education in the public and private spheres, Oxford Review of Education, 39:4, 464-479

Qualifications and Curriculum Authority (1998). Education for citizenship and the teaching of democracy in schools. Final report of the advisory group on citizenship. London, QCA.

Ramalingam, V. and Griffith, P. (2015). Saturdays for success. How supplementary education can support pupils from all backgrounds to flourish. (London, IPPR).

Rose, A. (2013) Exploring the relationship between supplementary schools and ‘cohesive communities', International Journal of Inclusive Education, 17:11, 11351151.

Schiffman, H. F. (nd). Language, Language Policy, and Citizenship. ccat.sas.upenn.edu/ haroldfs/public/3Views4.doc, accessed 29 January 2016.

Seddon, N., Cowen, N., and Tree, O. (2006). Supplementary schools: civil society strikes back. Civitas Review, 3,4, pp. 4-14.

Shapiro, M. (1981). Language and political understanding: the politics of discursive practices. New Haven: Yale University Press

Starkey, H. (2002). Democratic citizenship, languages, diversity and human rights. Guide for the development of Language Education Policies in Europe From Linguistic Diversity to Plurilingual Education Reference Study The Open University, Milton Keynes. 
Strand S (2007) Minority Ethnic Pupils in the Longitudinal Study of Young People in England: Extension Report on Performance in Public Examinations at Age 16, Department for Children, Schools and Families. http://dera.ioe.ac.uk/7916/1/ DCSFRR029.pdf

Tereshchenko, A. \& Archer, L. (2015) Identity projects in complementary and mainstream schools: the views of Albanian and Bulgarian students in England, Research Papers in Education, 30:3, 347-365

Tereshchenko, A. \& Grau Cárdenas, V. V. (2013). Immigration and supplementary ethnic schooling: Ukrainian students in Portugal, Educational Studies, 39:4, 455-467,

UK Gov. (2011). Prevent. Available at:

https://www.gov.uk/government/uploads/system/uploads/attachment_data/file/97976/ prevent-strategy-review.pdf (accessed 28 January 2016)

Vaughan, R. (2015). Ofsted will inspect madrasas, says Cameron.

https://www.tes.com/news/school-news/breaking-news/ofsted-will-inspect-madrasassays-cameron (accessed 29 January 2016).

Van Avermaet, P. (Author), Extra, G. (Ed.) (2011). Language Testing, Migration and Citizenship: Cross-National Perspectives on Integration Regimes (Advances in Sociolinguistics)

Ventura, A. and Gomes, C. (2013), Supplementary education in brazil: Diversity and paradoxes, in Janice Aurini , Scott Davies , Julian Dierkes (ed.) Out of the Shadows: The Global Intensification of Supplementary Education (International Perspectives on Education and Society, Volume 22) Emerald Group Publishing Limited, pp.129 - 151

Walters, S. (2011) Provision, purpose and pedagogy in a Bengali supplementary school, The Language Learning Journal, 39:2, 163-175.

Whiteley, P. (2012). Does Citizenship Education Work? Parliamentary Affairs, 1-23. 
Winton, S. (2007). Does Character Education Really Support Citizenship Education? Examining the Claims of an Ontario Policy. Canadian Journal of Educational Administration and Policy, 66.

Zhang, W. (2014) The demand for shadow education in China: mainstream teachers and power relations, Asia Pacific Journal of Education, 34:4, 436-454

Zhou \& Li (2003). Ethnic language schools and the development of supplementary education in the immigrant Chinese community in the United States.

https://www.researchgate.net/profile/Min_Zhou3/publication/8897517_Ethnic_langua ge_schools_and_the_development_of_supplementary_education_in_the_immigrant Chinese_community_in_the_United_States/links/0c960536e03f11759f000000.pdf 